\title{
The Sequence of Ideational Grammatical Metaphor Wording Technique in Historical Text: A Systemic Functional Linguistic Approach
}

\author{
Alan Jaelani (Corresponding author) \\ Graduate School, Faculty of Humanities \\ Universitas Padjadjaran \\ Jl. Raya Bandung Sumedang Km. 21 Jatinangor, Sumedang, Indonesia \\ Tel: +6283821414123 E-mail: alan11004@student.unpad.ac.id \\ Eva Tuckyta Sari Sujatna \\ English Department, Faculty of Humanities \\ Universitas Padjadjaran \\ J1. Bandung-Sumedang Km. 21 Jatinangor, Sumedang, Indonesia \\ Tel: +62-22-7796482 E-mail: evatuckyta@unpad.ac.id
}

Received: 26-11-2013

doi:10.7575/aiac.ijalel.v.3n.2p.194
Accepted: 26-12-2013

Published: 01-03-2014

URL: http://dx.doi.org/10.7575/aiac.ijalel.v.3n.2p.194

\begin{abstract}
The discussion of ideational grammatical metaphor has been attracted the attention of many researchers because of its usefulness and effectiveness in packaging information. With the device, meaning expressed in one pattern of the grammar can be reconstructed in another pattern of the grammar. This study focuses on the sequence type of ideational grammatical metaphor, which is then termed the sequence of ideational grammatical metaphor. In this kind of metaphor, the realization of meaning in clause complex is packed into a single clause through some wording techniques. The main objective of the present study is to analyze the application of techniques and their functions in historical text. By using the main framework of Systemic Functional Linguistics (SFL) proposed by Halliday and Matthiessen (2004), it is concluded that two main techniques, with expansion and with projection, are used to construe two different features of information in historical text. Both expansion and projection wording technique pack the realization of features in clause complex into a single metaphorical clause.
\end{abstract}

Keywords: Ideational grammatical metaphor, technique, sequence, congruent, historical text

\section{Introduction}

Feature of information in historical text is constructed in a certain way. Historical text is categorized into genres which manage time, cause, and value in complementary ways, to recount historical episodes and to explain the reason they occurred from one or more angles (Martin \& Rose, 2008). Knapp \& Watkins (2005) categorize it into historical recount. The text documents the two features of information; logical events of cause-effect relationship and logical events of the argument and statement of historical characters. Biber and Conrad (2009) argue that in construing meaning, the causeeffect relationship are commonly constructed in clause complex with cause-effect construction while the arguments and statements of historical characters are commonly constructed in clause complex with verb+that-clause construction.

In some occasions, however, the two features of information are constructed in a simple clause rather than in clause complex for certain purposes. When they are realized in a simple clause, the construction would be basically the result of meaning and structure reconstruction from the clause complex. The reconstruction is useful as a strategy to reduce longer clausal construction and make information more condensed, more tightly packed, and more abstract. The clause, then, becomes more complex lexically because information is condensed in group rank of a clause. The group rank may serve as semantic functions such as participant, process, and circumstance.

Based on the perspective of Systemic Functional Linguistic (SFL), ideational grammatical metaphor plays a significant role in reconstructing and condensing information. Halliday \& Matthiessen (2004) argue that the sequence type of ideational grammatical metaphor changes clause complex into a clause by some downgrading techniques. Nominalization, as its most important device, condenses information by turning processes in clause into nominal entity. The change of processes, then, leads to the reduction of clause. This makes longer clausal construction becomes the short one.

There has been much research which has followed the theory of grammatical metaphor proposed by Halliday such as the research in the volume of Simon-Vandenbergen et al. (2003). Most of their studies focus on the two types of grammatical metaphor in general, interpersonal and ideational one. They represent some of their most recent development. Other studies have also dealt with the distribution of grammatical metaphor in some kinds of scientific 
texts such as politics, economics, business, pharmacy, and media under science. Hadidi \& Raghami (2012), for instance, compare ideational grammatical metaphor in business and political texts. The main objective of their work is to see the distribution of ideational grammatical metaphor and its function in the two kinds of text.

Based on the previous research mentioned above, most of the studies focus on the distribution of the two types of grammatical metaphor in some kinds of text under science. In this study, however, the present writers would like to take more specific discussion on a kind of ideational grammatical metaphor, the sequence. The term the sequence of ideational grammatical metaphor is used to refer to the classification. The feature is discussed as it has certain ways in reconstructing meaning from clause complex to a simple clause by using some techniques of wording. The distribution and function of each technique in the corpus of this study would be analyzed based on the theoretical framework of Halliday and Matthiessen (2004). The other kind of scientific discourse, historical text, is considered as the main corpus of this study. It is also essential to analyze as the two features of information in historical text are constructed in certain ways. Thus, it is an interesting area for the analysis and discussion. Based on the rationale above, the research questions for this study are: What kinds of the sequence of ideational grammatical metaphor wording technique used in historical text? What are the functions of the sequence of ideational grammatical metaphor wording techniques in historical text?

\section{Theoretical Background}

Systemic Functional Linguistics (SFL) is defined as the theory of choice. Halliday \& Webster (2009) assume that there are more ways than one to convey meaning. In this regard, Bloor and Bloor (2004, p. 2) argue that, "grammar becomes a study of how meanings are built up through the choice of words". In line with the arguments, Eggins (2004) explains that the creative potential comes from the grammar in which a noun can be turned into a verb, adjective, adverb, etc. and thus use it in a range of structures to make different meanings. The theory of choice is further modeled in the concept of grammatical metaphor.

Grammatical metaphor was first introduced by Halliday in his An Introduction to Functional Grammar (1985). He extends the traditional notion of lexical metaphor by including metaphorical concept in the grammar. In the case of grammatical metaphor, Derewianka (2003, p. 188) argues that "what is varied is not the lexis but the grammar". In line with the argument, Halliday \& Webster $(2009$, p. 3) explain "grammatical metaphor involves the junction of category meanings, not simply word meanings". Thus, this kind of metaphor has different realization from the lexical metaphor. In this sense, grammatical metaphor is defined by Eggins (2004 p. 9) as "the situations where meanings typically (congruently) realized by one type of language pattern get realized by other less typical or metaphorical (noncongruent) linguistic choices."

In the realization, Martin \& White (2005, p. 163) argue "grammatical metaphors involves one category (a quality or a process) being presented as if it were another category (a thing/entity)." As it involves the junction of category meanings, grammatical metaphor can not be separated from its device, nominalization. Halliday \& Matthiessen (2004, p. 656) argue that "nominalization is the single most powerful resource for creating grammatical metaphor. By this device, processes (congruently worded as verbs) and properties (congruently worded as adjectives) are reworded metaphorically as nouns". As a result, Barlet (2004, p. 72) argue that "nominalization might reformulate a clause". It might reformulate clause complex to a clause and a clause to nominal group.

Eggins (2004, p. 119) believes that "grammatical metaphor is part of the creative potential that grammar offers language users." Halliday \& Martin (1993), Halliday \& Matthiessen (1999), Halliday \& Webster (2009), and (Halliday, 2004) give the following example to illustrate how grammar offers the creative potential meaning: "Glass cracks more quickly the harder you press on it". In the example, the clause has two processes, cracks and press, along with their associated participants and circumstances. It is believed that it is not just the only way the events are construed. Rather, it can be re-expressed with a different level such as "The rate of glass crack growth depends on the magnitude of stress". The concept here is the processes which are first realized congruently by verbs, participant by noun, and circumstance by adverb are nominalized in the form of metaphorical expression. It also proves that nominalization reformulates clause complex to a clause. In this sense, Gerot \& Wignell (1994, p. 147) state "Halliday uses the term metaphorical to contrast with the term congruent."

Grammatical metaphor relates to the concept of metafunctions in SFL. Taverniers (2006, p. 325) states "Being a functional theory of language, SFL conceives of language as being organized in terms of three general functional components, which are called metafunctions." In this regard, Matthiessen et al. (2003, pp. 110-111) state "there are two basic kinds of grammatical metaphor, differentiated in terms of the metafunctional model of meaning: interpersonal grammatical metaphor and ideational grammatical metaphor." In this study, however, the second type of grammatical metaphor is mainly focused. In the realization, Halliday and Matthiessen (2004) believe that "the general tendency for ideational metaphor is to 'downgrade' the domain of grammatical realization of a semantic sequence, figure or element - from clause nexus to clause, from clause to group/phrase, and even from group or phase to word." The clause nexus here refers to the clause complex.

Ideational metafunction relates to the system of transitivity. This leads Halliday (1994) to the assumption that ideational grammatical metaphor is called metaphors of transitivity. In line with the assumption, Taverniers $(2003$, p. 8) explain the reason is that "the grammatical variation between congruent and incongruent forms applies to transitivity configurations and can be analyzed in terms of the functional structure of the configurations." Thus, in its analysis, the congruent and incongruent/metaphorical forms are compared to see the grammatical contrasts between the constituents. 
Halliday and Matthiessen (2004) explore the nature of ideational grammatical metaphor in more depth by locating it in a broader theoretical environment. They argue that there are three types of ideational grammatical metaphor; sequence, figure, and element. Halliday and Matthiessen (1999) explain that in the congruent mode, a sequence is realized in clause complex, a figure in a clause, and an element in group. They claim that the three resources may be expanded by taking up further options in realization; such as, a sequence of two figures (clause complex) is alternatively realized in a clause. Based on the arguments, it can be said when the congruent realization of sequence is downgraded into a figure, a figure into an element, and an element into noun, it results metaphorical form. In this study, the metaphorization of the sequence resource is focused.

In the sequence type of ideational grammatical metaphor, Halliday \& Matthiesen (2004) assume that in the congruent mode, a sequence of two figures is realized in clause complex; but in the metaphorical mode, the domain of realization is downgraded from clause complex to clause. They claim that "the successive steps in downgrading are possible because both projection and expansion are motifs that are manifested throughout the grammatical system: a sequence of projection and expansion can thus be realized not only by the manifestation of projection in the clause complex, but also by its manifestation in the clause or the group/phrase." (p. 646).

Expansion, according to Bloor \& Bloor (2004, p. 282), is "one of a pair of alternative functions of a continuing clause or dependent clause in a clause complex." In line with the assumption, Halliday \& Matthiessen (2004, p. 376) argue that "in expansion, the secondary clause expands the primary clause, by elaborating it, extending it, or enhancing it." Projection, according to Bloor \& Bloor (2004, p. 287), “... expresses a representation of speech or thought rather than a direct representation of experience; the projection is direct or indirect speech (or thought), respectively paratactic and hypotactic." In line with the assumption, Halliday \& Matthiessen $(2004$, p. 376) argue that "the secondary clause is projected through the primary clause, which instates it as a locution or an idea." In short, Halliday \& Matthiessen (2004) argue that expansion relates to phenomena as being of the same order of experience, while projection relates to phenomena of a higher order of experience (what people say and think). The manifestation of both expansion and projection above is in the congruent form of clause complex. However, as Halliday \& Matthiesen (2004) argue, they can also be manifested in a clause or the group/phrase. Thus, the manifestation in the downgraded clause creates the ideational grammatical metaphor.

The theoretical framework of Halliday \& Matthiessen (2004) above is used in this study in determining the sequence of ideational grammatical metaphor wording techniques.

\section{Data and Method}

The data of this study are taken from a popular history book entitled "A Short History of Indonesia: The Unlikely Nation?" writen by Colin Brown (2003). The book is categorized into historical text under science. The book is read thoroughly to identify the application of the sequence type of ideational grammatical metaphor in the text. The data are then classified based on the downgrading techniques of Halliday \& Matthiessen (2004) and followed by the analysis of their function. The identified data are unpacked into a (more) congruent agnate form based on the theory of congruency proposed by Halliday \& Matthiessen (1999, pp. 246-247). Both metaphorical and congruent forms are shown to compare their semantic and transitivity configuration and to see how the techniques are applied in construing meaning of the two features in historical text. Using note taking, the data are analyzed and followed by description.

\section{Result and Discussion}

The focus of this study is the sequence of ideational grammatical metaphor wording techniques used in historical text, along with their functions. It is found that there are two main techniques used in the reconstruction of the two different features of information in historical text; with expansion and with projection. Both techniques have their own realizations.

\subsection{With Expansion}

One feature of information in historical text is the logical events of cause-effect relationship. In the congruent mode, the feature is realized in clause complex connected by causal relator. However, in the metaphorical mode, they are realized in a simple clause. In this regard, when the realization is in the form of ideational grammatical metaphor, the feature is constructed with the manifestation of expansion. In this technique of expansion, one or both figures in the clause complex are downgraded. The causal relator which is used to show the logical relation between events can be manifested as thing or process.

The first technique of expansion is used to pack the cause of event into circumstantial element. By this technique, the amount of lexical density is increased in the circumstantial element of metaphorical form. The realization of this technique is constructed based on the argument of Halliday \& Matthiessen (2004) that one figure of the sequence may be realized congruently by a clause, while the other is realized metaphorically as a prepositional phrase serving as a circumstantial element within that clause. Here, the relator of the sequence is realized as the minor process of the phrase. The relator and the minor process are matched in terms of subtype of expansion. In the following data, the causal relator because is realized by causal preposition because of as the subtype of expansion. Data (1), (2), and (3) represent the application of this realization of technique. 
(1) Metaphorical : Trade between Indonesia and China increased substantially during the Majapahit era because of changes in commercial policy in China.

Congruent : Trade between Indonesia and China increased substantially during the Majapahit era because commercial policy in China changed.

(2) Metaphorical : Because of the destruction of Kartasura, in 1746 the capital was moved to the village of Solo.

Congruent : Because Kartasura was destroyed, in 1746 the capital was moved to the village of Solo.

(3) Metaphorical : Due to political upheavals in India, the quality of the cloth they imported had fallen.

Congruent : Because politic in India was disruptive, the quality of the cloth they imported had fallen.

The metaphorical forms of the data above involve a change of clause, from clause complex to a clause. In this realization, the change of clause only occurs in the dependent clause (the cause of event). The dependent clause is packed into prepositional phrase serving as a circumstantial element through nominalization and the manifestation of expansion in the metaphorical form.

In the prepositional phrase serving as circumstantial element in data (1), the causal preposition because of is a result of the reconstruction of the causal relator because in its congruent form. Its qualifier changes in commercial policy in China is also the result of reconstruction from the clause commercial policy in China changed. In the clause, the material process changed is turned metaphorically to noun changes and the participant commercial policy in China is turned as a qualifier of noun changes. The reconstructed forms are packed metaphorically into prepositional phrase because of changes in commercial policy in China serving as a circumstantial element.

In data (2) and (3), the reconstruction is similar to data (1). The causal prepositions because of and due to are the result of the reconstruction of the causal relator because in their congruent forms. The qualifier the destruction of Kartasura is also derived from the reconstruction of clause because Kartasura was destroyed. Here, the material process destroyed is turned metaphorically to noun destruction while the participant Kartasura is turned to a qualifier of Kartasura. It qualifies the noun destruction. They are then combined into prepositional phrase because of the destruction of Kartasura serving as a circumstantial element in the metaphorical form. In data (3), the downgrading involves a change of relational process. The nominal group political upheavals in India is derived from the reconstruction of the clause politic in India was disruptive. In the clause, was is relational process. Their combination becomes prepositional phrase due to political upheavals in India serving as a circumstantial element in the metaphorical form.

The reconstruction of congruent form in data (1), (2), and (3) above is the same where the cause of event in the clause complex is realized metaphorically to a circumstantial element in a clause. The difference lies in the level of textual status. In data (1), the circumstantial element serves as rheme while in data (2) and (3) as theme. This confirms the argument of Halliday \& Matthiessen (2004, p. 602) that "when the domain of manifestation of expansion is a simple clause, the potential textual status of the manifestation of the cause depends on how it manifested. When it is manifested within a circumstance of cause, the cause may be given the status of either theme or rheme."

In the following data (4), (5), and (6), the technique of expansion is used to pack the cause and effect of event into participants in a circumstantial relational clause. In this realization, the change of clause not only occurs in the cause of event but also in the effect one. Here, the cause and effect relation is linked by some particular processes in one single clause of metaphorical form. In the realization, Halliday \& Matthiessen (2004) argue that both figures of the sequence may be realized metaphorically as token and value in a circumstantial relational clause. The relator of the sequence is realized, also metaphorically, as the process element in the clause. The expansion type of the relator is matched by the nature of the circumstantial verb for internal cause. In this regard, Halliday \& Matthiessen $(2004$, p. 243) state that "circumstantial verbs encode the circumstance of time, place, accompaniment, manner, etc. as a relationship between the participants." The verbs found in this classified data are lead to, produce, and cause. They encode the circumstance of reason. This can be seen in the analysis bellow.

(4) Metaphorical : Rising growth rates led to substantial inroads being made into poverty.

Congruent : Because economy grew increasingly, inroads were being made substantially into poverty.

(5) Metaphorical : In Java, the material ejected by these volcanoes and mixed with the naturally occurring soils produces a very fertile soil.

Congruent : In Java, because the material was ejected by these volcanoes and mixed with the naturally occurring soils, soil becomes very fertile.

(6) Metaphorical : The dry weather caused a substantial drop in rice production.

Congruent : Because the weather was dry, rice production dropped substantially.

Based on the data above, the nominalization occurs more densely. It involves the change of all semantic functions from the congruent form such as participant, process, and circumstance. It turned not only one clause but also both dependent and independent clause. The domain of realization of both dependent and independent clause are also, in turn, downranked from clause to nominal group functioning as participants serving as token and value in a circumstantial relational clause.

In the nominal group serving as token in data (4), rising growth rates is derived from the reconstruction of clause economy grew increasingly. The process grew is turned metaphorically to thing growth, the circumstance of manner 
increasingly is turned to classifier rising, and the participant economy has been left implicitly. In the nominal group serving as value, substantial inroads being made into poverty is derived from the reconstruction of clause inroads were being made substantially into poverty. In the clause, the process were being made is turned metaphorically into qualifier being made which then modifies the noun inroads. The circumstance of manner substantially is turned to epithet substantial modifying the noun inroads. Then, the process element led to in the metaphorical form is derived from the relator because in its congruent form. This circumstantial process relates the two nominal groups serving as token and value. It encodes the causal relation.

The same principle applies to the metaphorical form of data (5) and (6) where the process elements, might have been driven and caused, are the result of the reconstruction of the logical relator because in the congruent form. The nominal groups serving as value and token are also derived from the reconstruction of clauses in the congruent forms. In the nominal group serving as token in data (5), the material ejected by these volcanoes and mixed with the naturally occurring soils is derived from the reconstruction of clause the material was ejected by these volcanoes and mixed with the naturally occurring soils. The nominal group serving as value, a very fertile soil, is derived from the reconstruction of clause soil becomes very fertile. In the nominal group serving as token in data (6), the dry weather ${ }_{2}$ is derived from the reconstruction of clause the weather was dry. The nominal group serving as value, a substantial drop in rice production, is derived from the reconstruction of clause rice production dropped substantially.

Based on the description above, the cause and effect of events realized congruently in clause complex are reconstructed metaphorically into a single clause. This causes high lexical density in the clause. This is in line with the argument of Taverniers (2003: 26) that "grammatical metaphor, which construes processes as nominal groups, makes it possible for two process meanings to be linked to each other within a clause; this type of incongruent construal leads to a higher lexical density (more lexical words in the same clause) and a lower grammatical intricacy (the systems of clause complexing are avoided)."

Similar to the previous function, the following function of expansion is used to pack the cause and effect of an event into participants; but here the realization is in an intensive relational clause not in a circumstantial relational clause. The realization is constructed based on the argument of Halliday \& Matthiessen (2004) that both clauses of the sequence may be realized metaphorically as token and value in an 'intensive relational' clause; but the relator is nominalized as the thing of the nominal group, and the expanding clause is embedded as a qualifier. The nominalized relator is categorized into a noun of expansion such as time, place, cause, result, reason. In this regard, Halliday \& Matthiessen (2004: 426) argue that "embedding is a semogenic mechanism whereby a clause or phrase comes to function as a constituent within the structure of a group, which itself is a constituent of a clause." It means that one of the clauses in the congruent form is nominalized and embedded to the noun of expansion as nominalized relator. The following data represent the use of this realization of technique.

(7) Metaphorical

Congruent

(8) Metaphorical

Congruent

(9) Metaphorical

Congruent
: One result of this growing economy was the emergence of an urban middle class.

: Because economy was growing, an urban middle class emerged.

: This inflow of money into rural Minangkabau was one of the major factors behind the strengthening of Islam at this time.

: Because money flowed into rural Minangkabau, Islam is strengthening at this time.

: One reason behind the British signing of the Treaty of London had been preservation of access to Acehnese ports.

: The British signed the Treaty of London because they wanted to preserve access to Acehnese ports.

Based on the data above, the congruent forms which are realized in clause complex are turned metaphorically to a clause. In the nominal group serving as token in data (7), one result of this growing economy is derived from the reconstruction of clause because economy was growing. The relator because is turned metaphorically to thing one result. It is embedded by a qualifier of this growing economy as a result of the reconstruction of clause economy was growing. In this clause, the material process was growing is turned metaphorically to classifier growing. It classifies the thing economy which has been turned from the participant. They are then served as the qualifier of the nominalized relator one result. In the nominal group serving as value, the emergence of an urban middle class is derived from the reconstruction of clause an urban middle class emerged. Here, the process emerged is turned metaphorically to thing emergence and the participant an urban middle class is turned to qualifier of an urban middle class. It qualifies the thing emergence.

Data (8) and (9) apply the same realization where the things factor and reason are the result of the reconstruction of the causal relator because in the congruent forms. They are also embedded by their qualifier behind the strengthening of Islam at this time and behind the British signing of the Treaty of London as the result of the reconstruction of clause Islam is strengthening at this time and the British signed the Treaty of London.

\subsection{With projection}

The other feature of information in historical text is the argument and statement of historical characters. In the congruent mode, the feature is realized in clause complex using verb+that-clause constructions. In this regard, when the realization is in the form of ideational grammatical metaphor, the feature is constructed with the manifestation of projection. In the projection wording technique of ideational grammatical metaphor, one of the clauses in congruent 
form, the projected clause, is reconstructed into nominal group functioning as participant or as qualifier. The two processes of projection namely verbal and mental process basically contribute to the realization.

The first technique of projection is used to pack argument and statement into participant. The technique of wording is realized based on the argument of Halliday \& Matthiessen (2004) that the projecting figure may be realized metaphorically as a verbal or mental clause, while the projected figure is realized metaphorically as verbiage or the phenomenon. In this case, Matthiessen et al. (2003) explain that verbiage is participant role in the transitivity structure of a verbal clause while phenomenon is in a mental clause. The realization of technique is applied in the following data.

(10) Metaphorical

: On 17 August in that year, the nationalist leaders Sukarno and Mohammad Hatta proclaimed Indonesian independence.

Congruent : On 17 August in that year, the nationalist leaders Sukarno and Mohammad Hatta proclaimed that Indonesia was independent

(11) Metaphorical : The party's leadership had indicated its lack of confidence.

Congruent $\quad$ : The party's leadership had indicated that it was less confident.

(12) Metaphorical : Suharto considered threats of regional separatism.

Congruent : Suharto considered that regional separatism was threatening.

The projecting figure of data (10), the nationalist leaders Sukarno and Mohammad Hatta proclaimed, is realized metaphorically as a verbal clause with verbal process proclaim. There is no reconstruction of the congruent form. However, its participant Indonesian independence serving as verbiage is a result of the reconstruction from the projected figure Indonesia was independent. Here, the change of clause from clause complex to a clause occurs. It is because the projected figure is turned into nominal group serving as participant.

In data (11) and (12), the projecting figures the party's leadership had indicated and Suharto considered, are realized metaphorically as a mental clause with verbal process indicate and consider. Like data (10), there is no reconstruction from their congruent forms. However, the participants its lack of confidence and threats of regional separatism are the result of reconstruction from their projected figures it was less confident and regional separatism was threatening.

In data (13) and (14), the technique of projection is used to pack argument and statement into a qualifier of projecting noun. The realization of this technique is based on the argument of Halliday \& Matthiessen (2004) that the projecting figure in a sequence may be realized metaphorically as a noun of projection serving as the head/thing of a nominal group and the projected figure as a downranked clause serving as qualifier. The realization of technique is applied in the following data.

(13) Metaphorical : The first of the Ming emperors took the view that trade with Indonesian states, and others in the southern region, should be controlled by the state and not by private traders.

Congruent : The first of the Ming emperors viewed that trade with Indonesian states, and others in the southern region, should be controlled by the state and not by private traders

(14) Metaphorical : By around mid-1956 the Jakarta government came to the conclusion that it was just not going to win a military campaign in Aceh.

Congruent : By around mid-1956 the Jakarta government concluded that it was just not going to win a military campaign in Aceh.

(15) Metaphorical : The first indications that the Japanese were considering seriously the question of Indonesian independence emerged in mid-1943.

Congruent : It is indicated firstly in mid-1943 that the Japanese were considering seriously the question of Indonesian independence.

Data (13) and (14) consist of mental process. In data (13), a noun of projection the view is derived from the reconstruction of projected figure the first of the Ming emperors viewed. Its qualifier, that trade with Indonesian states, and others in the southern region, should be controlled by the state and not by private traders, is the result of the metaphorical reconstruction of projecting figure trade with Indonesian states, and others in the southern region, should be controlled by the state and not by private traders. In data (14), the noun of projection conclusion is derived from the reconstruction of projected figure the Jakarta government concluded. The qualifier that it was just not going to win a military campaign in Aceh is the result of the reconstruction of projecting figure it was just not going to win a military campaign in Aceh.

In data (15), verbal process indication is involved in the noun of projection. It is derived from the reconstruction of projected figure it is indicated. Its qualifier that the Japanese were considering seriously the question of Indonesian independence is the result of the reconstruction from the clause the Japanese were considering seriously the question of Indonesian independence.

\section{Conclusion}

The present study of the sequence of ideational grammatical metaphor wording in a history textbook reveals that there are two major techniques of wording applied in historical text; with expansion and with projection. The expansion technique is used metaphorically to construe meaning of cause-effect relation while the projection technique is used 
metaphorically to construe meaning of the argument and statement of characters in historical text. There are three subfunctions identified in the techniques of expansion; to pack the cause of event into circumstantial element, to pack the cause and effect of event into participants in a circumstantial relational clause, and to pack the cause and effect of event into participants in an intensive relational clause. Meanwhile, there are two sub-functions identified in the techniques of projection: to pack argument and statement into participants and to pack argument and statement into qualifiers of projecting noun. Through the two techniques, logical relation in clause complex is reconstructed into a coherent logical sequence of a simple clause.

Understanding the sequence of ideational grammatical metaphor wording technique helps the writer create logical meaning in a single metaphorical clause. As a result meaning becomes more condensed, more tightly packed, more abstract, and more complex. It also implicitly helps the reader unpack lexical complexities in a text.

A limitation of the present study has been only in the two features of information in historical text with small number of data. In the future, it will be important to analyze the other features in order to get deeper analysis in the application of grammatical metaphor in historical text.

\section{Acknowledgements}

The present writers would like to thank Dr. Sutiono Mahdi as the research adviser for his careful reading and helpful comment. Our thanks are also extended to Neni Suryanih, Lutfi Ibrahim Hanif, Bayu Permana Sukma, Indra Nugraha, Pebriwati Kaban, Erdisa Dipidua, Ida Lisdawati, and Ana for their help and support.

\section{References}

Bartlett, T. (2004). Mapping Distinction: Towards a Systemic Representation of Power in Language. In L. Young, \& C. Harrison. (eds.) Systemic Functional Linguistics and Critical Discourse Analysis. New York: Continuum. 68-84.

Biber, D., \& Conrad, S. (2009). Register, Genre, and Style. New York: Cambridge University Press.

Bloor, T., \& Bloor, M. (2004). The Functional Analysis of English. Second Edition. London: Arnold.

Brown, C. (2003). A Short History of Indonesia: The Unlikely Nation?. Australia: Allen \& Unwin.

Derewianka, B. (2003). Grammatical Metaphor in the Transition to Adolescence. In, A.-M Simon-Vandenbergen, M. Taverniers, \& L. Ravelli, (eds.) Grammatical Metaphor: Views from Systemic Functional Linguistics. Amsterdam: Benjamins, 185-219.

Eggins, S. (2004). An Introduction to Systemic Functional Linguistics. London: Continuum.

Gerot, L., \& Wignell, P. (1994). Making Sense of Functional Grammar. Sydney: Tanya Stabler.

Hadidi, Y., \& Raghami, A. (2012). A Comparative Study of Ideational Grammatical Metaphor in Business and Political Texts. International Journal of Linguistics, 4(2), 348-365. http://dx.doi.org/10.5296/ijl.v4i2.1853

Halliday M. A. K., \& Matthiessen, C. (2004). An Introduction to Functional Grammar (3rd Edition). London: Arnold.

Halliday M.A.K., \& Webster, J. J. (2009). An Introduction to Functional Grammar (3rd Edition). Great Britain: Continuum.

Halliday, M. A. K., \& Martin, J. R. (1993). Writing Science: Literacy and discourse power. London : Flamer press.

Halliday, M. A. K., \& Matthiessen, C. M. I. M. (1999). Construing Experience through Meaning, a Language Based Approach to Cognition. New York: Norfolk.

Halliday, M.A.K., (1994). Introduction to Functional Grammar, Second Edition, London: Edward Arnold.

Knapp, P., \& Watkins, M. (2005). Genre, Text, Grammar: Technologies for Teaching and Assessing Writing. Sydney: University of New South Wales Press.

Martin, J. R. \& Rose, D. (2008). Genre Relations: Mapping Culture. London: Equinox.

Martin. J.R.., \& White P.R.R. (2005). The Language of Evaluation: The Appraisal Framework. London: Palgrave Macmillan.

Matthiessen, C. M. I. M., Teruya, K., \& Lam, M. (2010). Key Terms in Systemic Functional Linguistics. New York: Continuum.

Taverniers, M. (2003). Grammatical Metaphor in SFL: A Historiography of the Introduction and Initial Study of the Concept. In A.-M Simon-Vandenbergen, M. Taverniers, \& L. Ravelli, (eds.) Grammatical Metaphor: Views from Systemic Functional Linguistics. Amsterdam: Benjamins, 5-33.

Taverniers, M. (2006). Grammatical Metaphor and Lexical Metaphor: Different Perspectives on Semantic Variation. Neophilologus. 90(2): 321-332. http://dx.doi.org/10.1007/s11061-005-0531-y. 